\title{
O.I. ЧУПАШКО
}

Львівський національний медичний університет іл. Данила Галицького

\section{Передумови розвитку ендотеліальної дисфункції при експериментальному донозологічному гіпотиреозі}

Поліваріантний характер перебігу гіпотиреозу, його численні «клінічні маски», неспецифічна симптоматика на етапі доклінічного розвитку ускладнюють діагностичний пошук і застосування коректної терапевтичної тактики [3, 4].

Упродовж останніх десятиріч нагромаджено чимало відомостей про молекулярні механізми ядерних впливів тиреоїдних гормонів (ТГ). Завдяки об'ємній інформаційно-регуляторній мережі негеномних ефектів виникло нове бачення в ендокринній фізіології і патології щитоподібної залози (Щ3) [3, 6]. Відтак, дослідження позаядерних сайтів взаємодії, аналіз альтернативних сигнальних шляхів впливу ТГ уможливить більш глибоке розуміння дисфункції ЩЗ, а також сформує теоретичні підходи для впровадження можливих коригувальних середників.

(c) Чупашко O.I., 2015 
У літературі представлені дані щодо високої ймовірності розвитку атеросклерозу зі супровідною ендотеліальною дисфункцією у хворих на гіпофункцію щитоподібної залози $[1,2,5]$. Стратегічна анатомічна позиція ендотелію між циркулюючою кров'ю та непосмугованими міоцитами судин зумовлює його здатність сприймати гемодинамічні та гуморальні сигнали крові. Для означення потенційних можливостей судинного ендотелію запропоноване поняття «дисфункція ендотелію», що передбачає його фенотипічну модифікацію з розвитком дезадаптивного стану $[2,5]$. Це характеризується втратою чи дисрегуляцією критичних гомеостатичних механізмів, що функціонують зазвичай у нормальних ендотеліоцитах. Джерелом модифікації є ендотеліоцити та гладкі міоцити судин - клітини, особливо чутливі до оксидативного стресу. Патофізіологічні наслідки ендотеліальної дисфункції передбачають низку ознак хронічної судинної патології, наприклад, зміну проникності для макромолекул плазми (ліпопротеїнів низької щільності), тромбоз, запалення та патологічну вазореактивність. Метаболічною основою ендотеліальної дисфункції є зниження продукції монооксиду азоту та чутливості до нього, зростання реактивних форм кисню [8-10, 13]. Порушення вазодилятаційної функції при гіпотиреозі ймовірно спричинюється зниженням генерації вазодилятаційних субстанцій i/ чи резистентністю до них судинних гладеньком'язових клітин, спотворенням компенсаторних вазодилятаційних ефектів ендотелію [1, 2]. Однак механізми впливу латентного дефіциту тиреоїдних гормонів на стан системи оксиду азоту у взаємозв'язку з системою обміну холестерину, а також на специфіку вільнорадикальних перетворень у патогенезі розвитку ендотеліальної дисфункції вивчені недостатньо.

Мета дослідження. Зважаючи на взаємозв'язок згаданих вище патогенетичних ланок, що можуть провокувати розвиток ендотеліальної дисфункції при донозологічному гіпотиреозі, дослідити деякі параметри вільнорадикальних перетворень, що є детермінантами оксидативного стресу. Узагальнити холестериновий профіль та зміни концентрації одного зі стабільних метаболітів системи монооксиду азоту - нітрит-іона як маркера вазодилятаційної спроможності ендотелію.

Матеріали і методи дослідження. Дослідження проведені на статевозрілих білих щурах-самцях масою 180-220 г відповідно до чинних міжнародних вимог і норм гуманного ставлення до тварин (Конвенція Ради Європи, 1986).

Експериментальний гіпотиреоз моделювали методом, запропонованим Е.С. Детюк і співавт. (1979). Функціональну активність ЩЗ оцінювали за концентрацією тиреоїдних гормонів - трийодтироніну $\left(\mathrm{T}_{3}\right)$, тетрайодтироніну $\left(\mathrm{T}_{4}\right)$, тиреотропного гормону (ТTГ) в сироватці крові методом радіоімунного аналізу. Рівень пероксидного окиснення ліпідів (ПОЛ) оцінювали за вмістом дієнових кон'югатів (ДК) за допомогою методу Плацера в модифікації В.Б. Гаврилова, М.І. Мішкорудної (1983), ТБК-активні продукти (ТБКАП) - методом Р.А. Тімірбулатова, Є.I. Селезньова у модифікації М.Ф. Тимочка, В.Б. Мартинюк, С.М. Ковальчук (1991). Досліджували активність ензимів системи антиоксидного захисту (АОЗ) - глютатіонпероксидази (ГПО) (В.М. Моин, 1986), каталази (КАТ) (М.А. Королюк та ін., 1988), супероксиддисмутази (СОД) (В.А. Костюк та ін., 1990). У крові тварин контрольної і дослідної груп визначали вміст загального холестерину (XC), ХC ліпопротеїнів (ЛП) різної щільності, тригліцеридів. Перелічені параметри визначали на біохімічному аналізаторі Biosystems BTS-370 Plus із використанням реактивів фірми Biosystems. Метаболіти оксиду азоту - нітрит-іон визначали за методом L.C. Green et al. (1982).

Результати дослідження та їх обговорення. Гіперліпідемія, дисліпідемія є невід'ємною біохімічною складовою гіпотиреозу, а також одним із найбільш поширених чинників ендотеліальної дисфункції [3, 7]. 
Результати наших досліджень показали, що відтворена модель ранньої гіпотиреоїдної дисфункції характеризувалась такими змінами: рівень холестеролу ліпопротеїнів дуже низької щільності (ХС ЛПДНЩ) у тварин перебував у межах контрольних значень, натомість холестеролу ліпопротеїнів низької щільності (ХС ЛПНЩ) достовірно зростав; його частка відповідно становила 22,2 \% проти 14,6 \% у контролі. Щодо антиатерогенних фракцій ліпідів відстежено зниження вмісту холестеролу ліпопротеїнів високої щільності (ХС ЛПВЩ), значення якого становили $1,08 \pm 0,04$ ммоль/л проти норми $(1,35 \pm 0,09)$ ммоль/л $(p<0,05)$. Показані достовірно вищі значення коефіцієнта атерогенності щодо контрольної групи - відповідно $(0,530 \pm 0,035)$ проти $(0,370 \pm 0,024)$ $(p<0,05)$, або $143 \%$. У взаємозв'язку з наведеними вище змінами це однозначно може трактуватись як атерогенний патерн дисліпідемії. Результати власних досліджень не суперечать даним наукової літератури, де засвідчено, що при латентній гіпофункції ЩЗ у крові порушуються синтез і утилізація ліпідів, інгібуються механізми оксидації холестерину, знижується ефективність транспорту, метаболізму та елімінації атерогенних ліпопротеїнів із жовчю внаслідок зниження активності ліпопротеїнліпази $[3,4,6]$. Сучасне бачення ймовірних механізмів розвитку дисфункції ендотелію, індукованої гіперліпідемією, полягає в комплексній взаємодії поліфакторів, а саме - у активації біомаркерів оксидативного стресу, зростанні плазмової концентрації асиметричного диметиларгініну - ендогенного інгібітора ендотеліальної NO-синтази, а також оксидації ліпопротеїнів.

Резюмуючи викладене, вважаємо за можливе констатувати, що за неадекватного контролю тиреоїдних гормонів за станом ліпідного обміну формується атерогенний профіль дисліпідемії, що модифікує «ендокринну» функцію ендотелію. Це згодом змінюе баланс між вазоконстрикторними та вазодилятаційними чинниками, унаслідок чого переважають вазоспастичні ефекти та ін.

Однією з патогенетично визначальних ланок відтвореної донозологічної форми гіпотиреозу є розвиток оксидативного стресу, що ініціює надмірну продукцію кисневих радикалів, активацію механізмів ліпопероксидації. Це є пусковим механізмом ураження клітинних і субклітинних структур зі змінами їх анатомо-функціональної організації. Зокрема, зафіксовано достовірне зростання ТБК-активних метаболітів у крові, що перевищує параметри норми на $27 \%$, ДК - на $46 \%$.

Основні параметри прооксидантних реакцій ми трактували у взаємозв'язку з системою ферментів окисної протидії. Доведено зниження активності СОД - на 30,5 \%, ГПО - на 37,1 \% щодо норми. Зафіксовано зменшення активності каталази як у сироватці, так і в цільній крові відповідно на 24,8 і 20,9\% $(p<0,05)$.

Отримані результати свідчать про ініціацію за даних умов вільнорадикальних реакцій з утворенням реактивних форм кисню, що визначають подальший хід пероксидативних процесів. Підтвердженням активації оксигеназних реакцій є не лише вищі щодо контрольних величин значення проміжних і кінцевих продуктів пероксидного окиснення ліпідів, але й зниження основних ензимів антирадикальної дії (супероксиддисмутази) та антипероксидної дії, також загального індексу антиоксидантної активності.

Сьогодні підтверджено прямий кореляційний зв'язок між сироватковою концентрацією ТТГ та індикаторами оксидативного стресу, що свідчить про високу ймовірність тиреотропіну безпосередньо впливати на оксидативний клітиний метаболізм [7-10].

Попри це відомо, що оксидативний стрес є домінуючим медіатором низки захворювань, зокрема, гіпертонії, атеросклерозу, дисліпідемії $[11,12]$. Надлишкове утворення реактивних форм кисню або ж зниження антиоксидантного резерву універсально формують про- 
оксидантний дисбаланс у судинній системі. Реактивні кисневі радикали модулюють системи внутрішньоклітинної сигнальної передачі й шляхів транскрипції та ін. Вільні радикали нейтралізують монооксид азоту та його позитивні ефекти на серцево-судинну систему [1-3]. Це й актуалізує проблему вивчення змін у системі оксиду азоту за умов зниження контролю тиреоїдними гормонами.

Один із потенційних механізмів, що знижують біодоступність монооксиду азоту в ендотелії, - підвищений розпад NO внаслідок надмірної продукції супероксиду. Супероксидний аніон елімінує NO, в результаті чого утворюється пероксинітрит $\left(\mathrm{ONOO}^{-}\right)$. Супероксид також призводить до формування окиснених форм ліпопротеїнів низької щільності [5].

У крові тварин з експериментальним гіпотиреозом виявлено зниження вмісту одного з метаболітів циклу оксиду азоту - нітрит-іона $\left(\mathrm{NO}_{2}^{-}\right)$до $17 \%$ щодо контролю. Це, ймовірно, може бути однією 3 причин порушення вазодилятаційних ефектів при гіпотиреозі. Також слід ще раз наголосити, що адекватна продукція монооксиду азоту має антиатерогенний ефект, який полягає у пригніченні утворення комплексів окисненого холестерину з ліпопротеїнами низької щільності, запобіганні вазоконстрикторних ефектів серотоніну, тромбоксану та ін. [4, 5, 7].

Судячи з отриманих результатів, за умов доклінічного гіпотиреозу реалізується низка взаємозв'язаних патогенетичних механізмів, що зумовлюють розвиток ендотеліальної дисфункції. Про це свідчить розвиток дисліпідемії, що є структурно-функціональним тлом для атерогенезу, зниження активності NO-залежної компоненти вазодилятаційних ефектів ендотелію судин. Показано також, що ранні форми гіпотиреозу супроводжуються змінами оксидативної метаболічної складової. Відбувається надмірна продукція кисневих і ліпідних радикалів на тлі супресії ферментів антирадикальної та антипероксидної дії. Як наслідок розвивається оксидативний стрес. Узагальнення результатів власних досліджень, а також їх порівняльний аналіз із даними сучасної фахової літератури дає змогу оцінити специфіку взаємодії різних ланок метаболізму за відтвореної моделі, а також з'ясувати їх роль у розвитку фенотипової модифікації ендотелію. Це уможливить подальший пошук патогенетично обгрунтованих, адекватних методів і засобів корекції досліджуваної нозології.

Рекомендовано до друку колісією з біоетики

\section{СПИСОК ЛІТЕРАТУРИ}

1. Покровский В.И. Оксид азота, его физиологические и патофизиологические свойства / В.И. Покровский, Н.А. Виноградов // Терапевтический архив. - 2005. № 1. - C. 82-87 (Pokrovsky V. Nitric oxide, its physiological and pathophysiologicl properties / V. Pokrovsky, N. Vynogradov // Therapeutical archive. - 2005. - N 1. P. 82-87). 2. Фундалентальні механізми дії оксиду азоту на серцево-судинну систему як основи патогенетичного лікування ㄲï захворювань / О.О. Мойбенко, В.Ф. Сагач, M.M. Ткаченко [та ін.] // Фізіологічний журнал - 2004. - Т. 50, № 1. - С. 11-30 (Fundamental mechanisms of nitric oxide action on the cardiovascular system as a background of the pathogenetic treatment of its diseases / O.O. Mojbenko, V.F. Sagach, M.M. Tkachenko [et al.] // Physiol. Journ. - 2004. - Vol. 50, N 1. - P. 11-30). 3. Чyпашко O.I. Різні форми експериментального гіпотиреозу: метаболічні критерії, перспективи доклінічної діагностики, прогнозування / O.І. Чупашко // Клінічна та експериментальна патологія. - 2012. - Т. 11. - № 3. Ч. 1. - С. 177-180 (Chupashko O. Different forms of experimental hypothyrosis: metabolic criterias, preclinical diagnostics, prognozing / O. Chupashko // Clinical and Experimental Pathologiya. - 2012. - Vol. 11. $N$ 3. S. 1. - P. 177-180). 4. Association between thyroid hormones, lipids and oxidative stress biomarkers in overt hypothyroidism / A. Santi, M.M.M.F. Duarte, R.N. Moresco [et al.] // Clinical Chemistry and Laboratory Medicine. - 2010. - Vol. 48. - N 11. - P. 1635-1639. 5. Chen K., Popel A.S. Theoretical analysis of biochemical pathways of nitric oxide release from vascular endothelial cells / K. Chen, A.S. Popel // Free Radic. Biol. Med. - 2006. - Vol. 41, N 4. - P. 668-680. 6. Gzhegotsky M.R. Metabolic profile in 
experimental mild hypothyrosis: possible risk factor for atherosclerosis / M. Gzhegotsky, O. Chupashko // Матеріали 10-го Українського біохімічного з'їзду, 13-17 верес. 2010 p., м. Одеса. - Український біохімічний журнал. - 2010.- № 82, № 4 (дод. 2). - С. 58. 7. Evaluation of oxidative stress, the activities of paraoxonase and arylesterase in patients with subclinical hypothyroidism / E. Cebeci, F. Alibaz-Oner, M. Usta [et al.] / Journal of Investigative Medicine. - 2012. - Vol. 60. - P. 23-28. 8. Influence of thyroid dysfunction on liver lipid peroxidation and antioxidant status in experimental rats / M. Messarah, A. Boumendjel, A. Chouabia [et al.] // Experimental and Toxicologic Pathology. - 2010. - Vol. 62. - N 3. - P. 301-310. 9. Oxidative stress and enzymatic antioxidant status in patients with hypothyroidism before and after treatment / G. Baskol, H. Atmaca, F. Tanriverdi [et al.] // Experimental and Clinical Endocrinology and Diabetes. - 2007. - Vol. 115. - N 8. - P. 522-526. 10. Coria M.J. Serum oxidative stress parameters of women with hypothyroidism / M.J. Coria, A.I. Pastrøn, M.S. Gimenez // Acta Biomedica de l'Ateneo Parmense. - 2009. - Vol. 80, N 2. - P. 135-139. 1. Plasma thiobarbituric acid-reactive substance levels in subclinical hypothyroidism / L. Kebapcilar, B. Akinci, F. Bayraktar [et al.] // Medical Principles and Practice. - Vol. 16. - N 6. - P. 432-436. 12. The impact of thyroid activity variations on some oxidizing-stress parameters in rats / M. Messarah, M.S. Boulakoud, A. Boumendjel [et al.] // Comptes Rendus. Biologies. - 2007. - Vol. 330. N 2. - P. 107-112. 13. Serum total antioxidant status and lipid peroxidation marker malondialdehyde levels in overt and subclinical hypothyroidism // A.N. Torun, S. Kulaksizoglu [et al.] // Clinical Endocrinology. - 2009. Vol. 70. N 3. - P. 469-474.

Стаття надійшла до редколегії 31.03.2015

\title{
ПРЕДПОСЫЛКИ РАЗВИТИЯ ЭНДОТЕЛИАЛЬНОЙ ДИСФУНКЦИИ ПРИ ЭКСПЕРИМЕНТ АЛЬНОМ ДОНОЗОЛОГИЧЕСКОМ ГИПОТИРЕОЗЕ
}

\author{
О.И. ЧУПАШКО
}

Львовский национальный медицинский университет ил. Данила Галищкого

Результаты исследования показали, что при латентной форме гипофункции щитовидной железы инициируются механизмы активации оксидативного стресса. Обнаружено снижение одного из метаболитов цикла монооксида азота - нитрит-иона, что, вероятно, может быть одной из причин нарушения вазодилятирующих эффектов при гипотиреозе. Касательно показателей липидного профиля обнаружено статистически вероятное снижение холестерина липопротеидов высокой плотности, повышение концентрации холестерина липопротеидов низкой плотности, повышение индекса атерогенности, что свидетельствует о тенденции к атерогенезу. Следует полагать, что при данных условиях формируются метаболические и функциональные предпосылки к развитию фенотипической модификации эндотелия.

Ключевые слова: донозологический гипотиреоз, эндотелиальная дисфункция, липидный профиль, оксидативный стресс, нитрит-ион.

\section{PREDISPOSITION TO ENDOTHELIAL DYSFUNCTION IN EXPERIMENTAL SUBCLINICAL HYPOTHYROSIS \\ O. CHUPASHKO \\ Danylo Halytskyi Lviv National Medical University}

Subclinical hypothyroidism (SH) or mild thyroid failure reflect declined thyroid activity without clear symptoms, but with elevated thyroid stimulating hormone (TSH) and normal range free thyroxine $\left(\mathrm{FT}_{4}\right)$ and triiodothyronine $\left(\mathrm{FT}_{3}\right)$ as the diagnostic indicators. Thyroid hormones are associated with the oxidative and antioxidative status of the organism. Depression of metabolism due to hypothyroidism has been showed to decrease oxidant production and thus protects tissues against oxidant damage. Lipid peroxidation is reported to be high in hyperlipidaemia, which is a consistent biochemical feature in hypothyroidism. However, data on the oxidative status of hypothyroidism are limited and controversial. The endothelial dysfunction is one of the earliest signs for atherosclerosis, which is frequently observed in experimental and clinical investigations, prior to any overt manifestations of SH. The predisposition to ED under condition of atherosclerosis may be partially explained by the factors including changes in lipid profile, oxidative stress, disturbances in NO synthesis. Therefore, endothelial dysfunction would be 
a favorable trigger factor to investigate the correlation between $\mathrm{SH}$ and cardiovascular disease. Taking this into consideration, the present study was trying to establish novel aspects linking $\mathrm{SH}$ and endothelial function.

The experiments were carried out on the intact male rats (weight $180 \ldots 220 \mathrm{~g}$, control and experimental group). The model of mild thyroid failure was induced by oral administration of mercazolilum in doses of $3 \mathrm{mg} / \mathrm{kg}$ during 3 weeks. (method, proposed by E. Detyuk et al.). Function of thyroid gland was assessed by the serum concentrations of thyroid hormones - thyroxine $\left(\mathrm{FT}_{4}\right)$ and triiodothyronine $\left(\mathrm{FT}_{3}\right)$, thyroid stimulating hormone (TSH) by radioimmunoassay analysis. Total cholesterol (TCh), high-density lipoprotein cholesterol (HDL), low-density lipoprotein (LDL), atherogenic index, biomarkers of lipid peroxidation system - diene conjugates (DC) and thiobarbituric acid reactive substances (TBARSs), activity of antioxidant enzymes - superoxide dismutase (SOD), catalase (CAT), glutathione peroxidase (GPx) as well as metabolites of nitric oxide - nitrit-ion, under conditions of hypothyrosis were determined.

Parameters of free radical peroxide reactions were investigated in comparative interaction with enzymatic antioxidant defence. Activation of lipoperoxidation (LPO) processes has been established in rat blood. The concentration of thiobarbituric acid reactive substances in the blood significantly exceeds parameters of control values (due to the content of MDA - $27 \%, \mathrm{DC}-46 \%$ ). Enzymatic protection against reactive oxygen species (ROS) and the breakdown products of peroxidized lipids are provided by superoxide dismutase (SOD) and catalase (CAT). Correspondingly, the activity of antioxidant protection system was depressed (SOD - by 30,5 \%, GPx - by $37,1 \%$ compared to normal values). These data suggest the impairment of the antiradical protective link. A relationship between mild hypothyrosis and dislipidemia was established. Increase in serum levels of low-density lipoprotein, and reduction in HDL, and as a result, increase in atherogenic index $(0,530 \pm 0,035)$ was shown. With respect to parameters of nitric oxide system, the decreased level of nitrite-ion in rat blood, was also demonstrated. It should be emphasized that the observed changes can predict the tendency to endothelial dysfunction in SCH.

In conclusion, our study showed the changes in blood of the lipid profile, decrease in nitrit-ion concentration, activation of lipid peroxidation processes. It can be qualified as metabolical and functional precondition of endothelium disfunction under mild defficiency of thyroid hormones. However, further studies are necessary to evaluate a larger series of experimental groups, with a wider spectrum of biomarkers to analyze correlation between different links of metabolism in condition of mild hypothyroid function.

Key words: subclinical hypothyroidism, endothelial dysfunction, lipid profile, oxidative stress, nitrie ion. 